\title{
Conceptualising disability: Health and legal perspectives related to psychosocial disability and work
}

\author{
L van Niekerk, ${ }^{1}$ B Occ Ther, M Occ Ther , PhD; D Casteleijn, ${ }^{2}$ B Occ Ther, PG Dip Voc Rehab, M Occ Ther, DHETP, PhD; \\ A Govindjee, ${ }^{3}$ BA, LLB, LLM (Labour Law), LLD; W Holness, ${ }^{4}$ BA, LLB, LLM; \\ J Oberholster, ${ }^{5}$ B Occ Ther; C Grobler, ${ }^{6}$ MB ChB, DOH, FC Psych, MMed Psych, MD \\ 1 Division of Occupational Therapy, Department of Health and Rehabilitation Sciences, Stellenbosch University, Cape Town, South Africa \\ ${ }^{2}$ Department of Occupational Therapy, School of Therapeutic Sciences, Faculty of Health Sciences, University of the Witwatersrand, Johannesburg, \\ South Africa \\ ${ }^{3}$ Faculty of Law, Nelson Mandela University, Port Elizabeth, South Africa \\ ${ }^{4}$ Department of Public Law, School of Law, University of KwaZulu-Natal, Durban, South Africa; Navi Pillay Research Group, Durban, South Africa \\ ${ }^{5}$ Siyaya Skills Institute, Port Elizabeth, South Africa \\ ${ }^{6}$ Department of Psychiatry, Elizabeth Donkin Hospital, Port Elizabeth, South Africa
}

Corresponding author: L van Niekerk (lanavn@sun.ac.za)

\begin{abstract}
Background. Work has been found to improve health outcomes and increase quality of life. It is also a vehicle through which people develop personally, earn an income and meet other needs, as it is recognised as a social determinant of health. However, persons with psychosocial disability face many barriers in their quest to achieve equality, experiencing ongoing marginalisation and exclusion from full participation in work.

Objectives. To explore the nexus between South Africa's progressive Constitutional and legislative context, employers and the provision of health- and law-related services facilitating participation of persons with psychosocial disability in work.

Methods. The authors, with diverse professional backgrounds, namely law, psychiatry and occupational therapy, developed a synthesised perspective to highlight issues that require consideration and to develop guiding principles from which practitioners can draw to support the participation of persons with psychosocial disability in work.

Results. A perspective is shared to provide direction and inform practice aimed at promoting participation of persons with disability in work. Conclusion. Health professionals are reminded of their ethical duty to support persons with psychosocial disability to either stay at work or return to work as soon as possible. The potential dangers of sick leave in the absence of a return to work plan are highlighted, and the need for a multi-professional approach is emphasised.
\end{abstract}

S Afr J Bioethics Law 2020;13(1):43-51. https://doi.org/10.7196/SAJBL.2020.v13i1.689

The former South African (SA) Minister of Health highlighted the continued burden of disability, stating: 'Disability has far-reaching effects on the health and socioeconomic status of households and communities, and people with disability continue to be disproportionately represented among the extremely poor. ${ }^{\prime[1]}$ This despite disability rights being enshrined in the Constitution of the Republic of SA of 1996, our nation's status as a signatory to the United Nations Convention on the Rights of Persons with Disabilities ${ }^{[2]}$ and the adoption of progressive labour and social protection legislation.

In spite of the protection of the rights of persons with disabilities by the Constitution, together with progressive legislation designed to protect against discrimination and stimulate accommodation in the workplace, a number of gaps remain that leave persons with disability vulnerable. One of the most important of these gaps relates to the definition of what constitutes disability in terms of mental illness. The way disability is understood and defined has a direct impact on how legislation is applied in protecting and promoting the rights of persons with disabilities. The way legislation is interpreted and enacted will have implications for how opportunities to participate in work are created (e.g. affirmative action initiatives) and safeguarded (e.g. protection against dismissal on grounds of disability), as well as the type of support available in the process of obtaining and sustaining work (e.g. reasonable accommodation).

The aim of this article is to explore the nexus between SA's progressive constitutional and legislative context, employers and the provision of health- and law-related services facilitating participation of persons with psychosocial disability in work. The ideas presented here originated from a collaborative project in which the authors, with diverse professional backgrounds (namely law, psychiatry and occupational therapy) developed a synthesised perspective designed to draw attention to issues that require consideration, and proposed guiding principles from which practitioners can draw. The intention was to formulate a perspective that will provide direction and inform practice aimed at promoting participation of persons with disability in work. This article is written on the premises that work is an essential ingredient required for people to develop and to meet their needs, 
and that participation in work is recognised as a social determinant of health. ${ }^{[3]}$ Work has been found to improve health outcomes ${ }^{[4]}$ and increase quality of life. ${ }^{[5]}$ We recognise the injustice of ongoing marginalisation and exclusion of persons with psychosocial disability from full participation in work, and recognise the many barriers faced by persons with disability in their quest to obtain equality. The cost to society of excluding people with disabilities from taking an active part in community life is high. Harnois and Gabriel ${ }^{[6]}$ pointed out that 'disability not only affects individuals but also impacts on the entire community', and highlighted the resultant loss of human potential and reduced productivity when persons with disability are excluded. Exclusion of persons with disability from work has financial, developmental, social and emotional consequences.

A necessary first step in the process of conceptualising disability is to make sense of the terms and definitions used in the field. We start by acknowledging that all terminology used for diagnostic or disability categories shares the disadvantage that people are labelled in one way or another, and that these labels tend to set people apart in ways that those being labelled experience as negative. One of the main criticisms of the medical model approach is that problems experienced are situated within the person. ${ }^{[7]}$ Conversely, the social model of disability recognises that social contexts, shaped by misunderstanding, ignorance or even fear, can create barriers that prevent or limit opportunities for persons with disability to participate on an equal footing. ${ }^{[7]}$ Our use of the term 'disability', aligned with the social model of disability, therefore recognise society's responsibility for inclusivity, and the need for reasonable accommodation. Medical diagnostic categories classify health conditions according to symptoms, thus emphasising problems or deficits, and for this reason we use 'psychosocial disability', rather than the term 'persons with mental illness.' However, in choosing to use psychosocial disability, we recognise two potential pitfalls: the first, reduced specificity of what exactly constitutes disability for purposes of assessment or classification, and the second, a blurring of the boundaries between what constitutes sickness in a sense that would allow access to certain advantages or privileges to be attached to the status. We recognise the tension between narrow ${ }^{[8]}$ and broader ${ }^{[9]}$ conceptualisations of disability, the former being particularly useful in determining who qualifies for disability status, and thus can expect support and reasonable accommodation, while the latter might avoid disability arising in the first place by creating a supportive, inclusive environment to begin with. Favalli and Ferri ${ }^{[10]}$ note that the United Nations Convention on the Rights of People with Disabilities (CPRD) does not contain definitions for disability or persons with disability because 'the idea that disability is a flexible and evolving concept prevailed! ${ }^{\text {[10] }}$ We follow the lead of the CPRD in an attempt in an attempt to be as inclusive as possible.

The issue of promoting participation of persons with disability in work-related activities is complicated by the many definitions that have been formulated for the notion of disability itself. Depending on the theoretical assumptions on which they are built, definitions vary greatly. They also differ according to the purpose for which the definition is intended. ${ }^{[1]}$ The United Nations, in its Convention on the Rights of Persons with Disabilities, ${ }^{[2]}$ has published a comprehensive definition which Disabled People SA has adopted. ${ }^{[12]}$ This definition reads: 'Those who have long-term physical, mental, intellectual or sensory impairments which, in interaction with various barriers, may hinder their full and effective participation in society on equal basis with others. ${ }^{[2]}$

The SA Constitution enshrines four pertinent rights: equality; ${ }^{[13]}$ dignity; ${ }^{[14]}$ fair labour practices; ${ }^{[15]}$ and freedom of trade, occupation and profession. ${ }^{[16]}$ The last two are labour-specific rights. These four rights promote participation in the workplace in a non-discriminatory, dignity-enhancing manner. Exclusion from the workplace not only directly affects labour rights, and can be discriminatory, but impacts on the dignity of the affected individual. ${ }^{[17]}$ The right to equality entails both eradication of discrimination, a negative aspect of the right, and introduction of positive measures, such as accessibility promotion and reasonable accommodation measures. ${ }^{[10]}$ The jurisprudence of our courts promotes substantive equality, which involves preference of equality of outcomes, and celebrates difference and diversity, but requires the positive duties, alluded to earlier, in order to promote equality. ${ }^{[18]}$

The Employment Equity Act No. 55 of 1998 defines persons with disability as 'people who have a long-term or recurring physical or mental impairment which substantially limits their prospects of entry into, or advancement in, employment.. ${ }^{[19]}$ The Department of Social Development of SA manages disability grants (among other social security interventions) and defines disability as a 'moderate to severe limitation to [one's] ability to function as a result of a physical, sensory, communication, intellectual or mental disability rendering him or her unable to (a) obtain the means needed to enable him or her to provide for his or her own maintenance; or (b) be gainfully employed.'[20]

It is notable that the Employment Equity Act places emphasis on considering impairment and whether or not that impairment is substantially limiting with a view to ascertaining the prospects of entering into, or advancing in, employment. ${ }^{[2]]}$ The Department of Social Development, by contrast, focuses on the ability to perform daily activity, setting the standard for disability beyond mild disability, and requiring moderate to severe limitation for access to disability grants. ${ }^{[20]}$ It is clearly necessary to be aware of the specific definition that has been adopted by the legislature, service provider or organisation prior to advocating for the rights of persons with disabilities.

\section{The legislative framework within which decisions are made and actions taken}

The Disability Rights Charter of SA of 1992 promotes equal opportunities for persons with disability by asserting their rights to live independently in a safe environment, free from all forms of discrimination, exploitation and abuse. ${ }^{[2]}$ This charter, developed by disabled people, for disabled people, demonstrates the political impetus for the protection of disabled people's rights. Furthermore, SA signed and ratified the 2007 United Nations Convention on the Rights of Persons with Disability ${ }^{[2]}$ that makes a strong argument for meaningful work for persons with disability, as well as the optional protocol that allows people to seek redress for treaty violations at an international level (once every avenue has been exhausted to change the situation at the national level). The new 2018 protocol to the African Charter on Human and Peoples' Rights on the Rights of Persons with Disabilities ${ }^{[23]}$ adopted by the African Union, and signed by $\mathrm{SA}$, will provide firm grounds for these rights in the African region 
when it comes into force. ${ }^{[23]}$ International and domestic law requires reasonable accommodations (also known as work adaptations) to be offered to persons with disabilities to ameliorate social and environmental barriers, among others, that negate their equal and full participation in work. Measures of reasonable accommodation, broadly speaking, are understood as 'necessary and appropriate modification and adjustments not imposing a disproportionate or undue burden, where needed in a particular case, to ensure to persons with disabilities the enjoyment or exercise on an equal basis with others of all human rights and fundamental freedoms.[2]

The Employment Equity Act focuses on redress as a major outcome. ${ }^{[24]}$ Because persons with disability are recognised as one of the designated groups that faced exclusion in the past, these persons are legally expected to be beneficiaries of affirmative action strategies and employment equity plans. This is necessary to promote their participation in work. The Employment Equity Act also protects employees, and job seekers, from unfair discrimination on the basis of various listed grounds, including disability. ${ }^{[25]}$ The Code of Good Practice $(2015)^{[26]}$ and the 2017 Technical Assistance Guidelines on the Employment of Persons with Disabilities ${ }^{[27]}$ were developed to guide the implementation of the Employment Equity Act and to provide a foundation for the development of affirmative action initiatives, and for the implementation of reasonable accommodation (new versions of these documents replaced earlier versions from 2002). The Employment Equity Act, ${ }^{[24]}$ together with the Code of Good Practice ${ }^{[26]}$ and the Technical Assistance Guidelines, ${ }^{[27]}$ provide a strong foundation for maintaining the participation of persons with disability in work through these antidiscrimination measures, which include the duty on the employer to reasonably accommodate an employee with a disability. The defence that is available to employers, where reasonable accommodation is not possible, is unjustifiable hardship. This concept is defined as 'any action requiring significant or considerable difficulty or expense.'[28,29] The code requires employers to consider the effectiveness of the accommodation, and whether it will 'seriously disrupt the operation of the business'.[26] In assessing and adopting appropriate measures to accommodate an employee with a disability, the employer must consider both the cost and quality of the measure 'consistent with effectively removing the barrier to a person being able to perform the job, and to enjoy equal access to the benefits and opportunities of employment.[28] This means that cost is not the only factor to be considered. The courts expect the employer to have articulated why it is not accommodating the employee, short of unjustifiable hardship, and to provide reasons for its decision. ${ }^{[36]}$

The Basic Conditions of Employment Act No. 75 of $1997^{[29]}$ and the Labour Relations Act No. 66 of $1995^{[30]}$ also play a role in reducing the risk of exploitation of persons with disability by, respectively, setting minimum standards of employment and making dismissal on the basis of disability as automatically unfair dismissal, subject to reinstatement or compensation equivalent to 24 months' remuneration.

The Skills Development Act No. 97 of $1998^{[31]}$ funds skills development, including learnerships and simulated training opportunities for persons with disability through Sector Education Training Authorities (SETAs). This Act promulgated tax incentives for employers who employ people with disabilities. Money allocated specifically for skills development, including learnerships, is available for the training.
The Promotion of Equality and Prevention of Unfair Discrimination Act No. 3 of $2000^{[32]}$ provides a framework within which complaints of unfair discrimination will be heard in the Equality Courts, when unfair discrimination on the basis of disability occurs outside of the workplace context and for those not covered by the Employment Equity Act. ${ }^{[24]}$ This would apply, for example, to workers who are not considered by law to be employees, but independent contractors. The broad-based black economic empowerment policy provides additional impetus for employment of persons with disability; incentives (financial and other) reward employers who employ people from designated groups. ${ }^{[33]}$ Significantly, proposed amendments to the Compensation for Occupational Injuries and Diseases Act No. 130 of 1993 in the Compensation for Occupational Injuries and Diseases Bill of 2018 ${ }^{[34]}$ specifically seek to provide for rehabilitation, reintegration and return to work of occupationally injured and diseased employees. Rehabilitation is defined in the proposed amendments to mean 'measures, services and facilities, also in the form of clinical, vocational and social rehabilitation provided for in chapter VIIA of the Act, provided with a view to the reintegration of employees exposed to an occupational injury or disease back into work and to enable them to attain and maintain, where reasonable and practicable, maximum independence, full physical, mental, social and vocational ability, and full inclusion and participation in all aspects of life. ${ }^{\text {! } 34]}$ Employees are, in terms of the proposed amendments, required to submit to medical examination and rehabilitation in appropriate circumstances. Importantly, the Compensation Fund may provide, as the case may be, facilities, services and benefits aimed at rehabilitating employees suffering from occupational injuries or diseases to return to their work and to reduce any disability resulting from their injuries or diseases. The rehabilitation benefits provided may consist of:

- clinical rehabilitation and the provision of assistive devices for the purpose of physical and psychological recovery of the employee, and to reduce any disability resulting from an occupational injury or disease;

- vocational rehabilitation to assist an employee to maintain employment, obtain employment, or regain or acquire vocational independence; and

- social rehabilitation to assist in restoring an employee's independence and social integration to the maximum extent practicable.

Despite the implementation of progressive legislation with a specific focus on redress, associated outcomes have been disappointing. There is a dearth of studies as to the success of persons with disabilities as a designated group in capitalising on this legislated equity advancement. Furthermore, lack of disaggregated data on disability (and impairment type) in the workplace makes it difficult to quantify this benefit. Statistics SA's most recent census report does not provide these data. ${ }^{[35]}$ The stigma that attaches to psychosocial disability means that fear of disclosure can scupper measures to promote equal participation in the workplace.

\section{Employers' level of preparedness to accommodate disability}

A review of court cases was undertaken to explore how psychosocial disability is understood by employers. Table 1 contains an excerpt of 
Table 1. Review of cases where employees with psychosocial impairment or disability were dismissed

Case name
Hendricks v Mercantile \& Genera
Reinsurance Co of SA Ltd (1994)
ILJ 304 (LAC)
Spero v Elvey International (Pty)
Ltd (1995) 16 ILJ 1210 (IC)

Ltd (1995) 16 ILJ 1210 (IC)

Automobile Association of SA v Govender No \& Others (1999) 20 ILJ 2854 (LC)

Rikhotso v MEC for Education (2004) 25 ILJ 2385 (LC)

New Way Motor \& Diesel Engineering (Pty) Ltd v Marsland (2009) 30 ILJ 2875 (LAC)

IMATU obo Strydom v Witzenberg Municipality (2012) 33 ILJ 1081 (LAC)

Western Cape Education Department v General Public Service Bargaining Council \& others (2013) 34 ILJ 2960 (LC)

L S v Commission for Conciliation, Mediation \& Arbitration \& Others (2014) 35 ILJ 2205 (LC)

MEC for the Department of Health, Western Cape v Weder; MEC for the Department of Health, Western Cape v Democratic Nursing Association of SA on behalf of Mangena (2014) 35 ILJ 2131 (LAC)

\section{Description}

\section{Category}

Employee with depression (and other physical illnesses) dismissed

5 for incapacity alleged unfair labour practices. The court held that the dismissal was fair as an attempt to accommodate the employee was offered by the employer - creation of a new, alternative position. The employee rejected this. The previous court's decision confirmed.

Employee with depression (and other disorders) dismissed for incapacity. Court held that the dismissal was unfair as the incapacity was temporary and the psychiatrist's report that the condition would improve was not considered and the employer did not offer alternatives to dismissal. Order of reinstatement confirmed.

Employee with depression dismissed for misconduct after assault and negligent driving while sedated from medication. The court held that the employee lacked the mental intention to commit the misconduct. Ordered that the arbitration had to start afresh and instructed the commissioner to consider the feasibility of an alternative position not requiring driving and interacting with members of the public to avoid such an incident reoccurring. Employee with depression and post-traumatic stress disorder applied unsuccessfully to be medically boarded. The court held that the dismissal for incapacity was fair due to the continued absenteeism and the employee's refusal to consider alternative positions, which gave the impression that the employee was only interested in being medically boarded.

Employee with depression argued constructive dismissal, which is automatically unfair. The court held that the employer's conduct constituted an egregious attack on the dignity of the employee (stigmatisation and bullying tactics were employed after the employer became aware of the mental illness of the employee); also that depression is protected as an analogous ground (health) and is not 'disability' per se. Ordered back, overtime and leave pay.

Employee with depression and post-traumatic stress applied unsuccessfully for medical boarding and was later dismissed for incapacity. The court held that dismissal on the basis of incapacity was unfair as the employer did not do a proper assessment of the employee's capability to continue working and a recent psychiatrist's report supporting resumption of duties was not considered. Ordered compensation.

Employee with depression and post-traumatic stress disorder alleged constructive dismissal when sick leave applications (temporary incapacity) were not processed by the employer and pay deducted for sick leave for a period of 2 years. The court held that the work situation was intolerable leading to the resignation of the employee. Employee had recovered psychologically and was better equipped to work. Ordered reinstatement.

Employee with post-traumatic stress disorder was dismissed for poor work performance. The court held that the dismissal was unfair as the employer did not enquire into the impact that the mental illness played on the capacity of the employee to perform her duties. Employer's own earlier psychologist recommendations were not followed. Ordered compensation.

, Two cases were consolidated: first, an employee with pulmonary tuberculosis, schizophrenia and major depression, and second, an employee with depression, were both dismissed for unauthorised absence despite submitting sick leave applications with medical certificates by their psychiatrists. The court held that the absence of plausible reasons for the dismissals and no evidence of an intolerable working relationship were offered. Order by previous court of reinstatement confirmed.
Reasonable accommodation measures

were offered to the employee.

Temporary incapacity; evidence psychiatrist's report not considered; alternatives to dismissal not offered.

Court did not mention reasonable accommodation.

Alternative positions were offered to the employee.

Conduct of employer is unfair discrimination on the basis of 'health'

Evidence - psychiatrist's report regarding return to work was not considered.

Conduct of the employer was such that the work environment was intolerable. No fair reason for the dismissal was offered by the employer.

Evidence - impact of mental illness on capacity was not considered.

Unclear whether notification to employers of sick leave applications by the employees were given. Nonetheless, the employer was required to offer plausible reasons for dismissal. The evidence of psychosocial illnesses of employees as the reason for the absence from work was not considered. 
Table 1. (continued) Review of cases where employees with psychosocial impairment or disability were dismissed

Case name
Transnet Rail Engineering v Minies
\& Others (2015) 36 ILJ 2605 (LAC)
Description

Category

Employee with depression dismissed for negligence. The court

held that the dismissal was unfair as the evidence of the mental condition was not considered and an opportunity to improve not offered. Further, doctor's recommendation that a transfer be effected to avoid further deterioration of his mental health was ignored. Order by previous court of reinstatement confirmed.

Gangaram v MEC for the Department of Health, KwaZuluNatal \& another (2017) 38 ILJ 2261 (LAC)

Pharmaco Distribution (Pty) Ltd v EWN (2017) 38 ILJ 2496 (LAC)

Jansen v Legal Aid South Africa (2018) 39 ILJ 2024 (LC)

MEC = Member of the Executive Council.
Employee with back injuries, some work-acquired, and depression, dismissed for misconduct due to alleged unauthorised work absences. The court held that the deemed dismissal was not supported by evidence as she did submit sick leave applications with medical certificates. Ordered reinstatement.

Employee with bipolar disorder suspended and requested to subject herself to medical examination to assess her suitability for the position, and when she refused, was dismissed for misconduct and refusing to obey a lawful instruction. The court held that neither the medical facts nor employment conditions justified medical testing. Further, that the clause in the contract requiring submission to medical testing was patently offensive and of no legal effect. The dismissal was automatically unfair and the conduct of the employer amounted to unfair discrimination on the basis of disability. Ordered compensation and reinstatement. Employee with depression dismissed for misconduct. The court held that dismissal was automatically unfair as it impinged on the dignity of the employee and amounted to unfair discrimination as the employer was aware of the employee's mental illness and the alleged misconduct was linked with the employee's mental health The court held that the employer failed to hold a capacity hearing and to accommodate the employee. Ordered reinstatement.
Evidence of impact of psychosocial

illness on work performance was not considered.

Notification of sick leave duly provided by the employer. No basis for deemed dismissal found. Court did not mention reasonable accommodation.

Conduct of employer is unfair discrimination.

Conduct of employer is unfair discrimination on the basis of the psychosocial illness.

Evidence of 'mental condition' ignored.
13 case summaries from the review, and illustrates that employers can be guilty of dismissing an employee with psychosocial impairment for incapacity or misconduct, rather than providing reasonable accommodation or adaptations to ensure the employee's continued participation in the workplace. The cases surveyed also demonstrate that such dismissals occur despite the psychosocial impairment generally being of a temporary (and impermanent) nature, particularly once the illness was optimally managed with treatment.

Professional medical and occupational reports are usually relied upon by employers to inform occupational decision-making. Based on the report of a psychiatrist, and sometimes that of an occupational therapist, the employer should be in a good position to ascertain not only the diagnosis of the employee, but the prognosis. In other words, the report should set out how the impairment affects the employee, and identify which reasonable accommodation measures, in the opinion of the professional after consultation with the employee, may be required for the employee to fully participate in the workplace. Three duties are placed on the employer once disclosure of an illness or disability is made: to investigate; to consult with the employee; and to implement reasonable accommodations. ${ }^{[36]}$

The challenge is that the point at which such a report or reports are obtained is not usually at the outset, when an employee requests reasonable accommodation measures. Rather, due to stigma, disclosure of psychosocial disability to employers generally occurs once a crisis point has been reached. The professional's report is usually obtained when the employer is considering taking measures to address what appears to be poor performance, misconduct or incapacity. Under the labour legislation, different procedures and enquiries follow such alleged incidents. Where an employee is thought to be incapacitated and unable to perform the essential functions of their job, the employer must initiate an incapacity proceeding. What has become clear from a review of court cases is that employers find it difficult to differentiate between when a person's illness and conduct in the workplace amounts to a disability or incapacity, both terms with legal protection and the consequences that flow from such categorisation (Table 1). An employee with a disability can often perform the essential functions of the job, but requires reasonable accommodation to do so. ${ }^{[37]} A$ person with temporary incapacity may not be able to perform those functions at a particular point in time, but would typically be able to do so once they recover (sometimes with accommodation measures, or in an alternative position).

In two reported cases, the psychiatrists' reports relating to the nature of the psychosocial impairment, the duration and the capacity of the employee to return to work were not considered by the employer. In those instances, the incapacity was temporary, yet the employers proceeded as if the incapacity was permanent, and dismissed the employees. The courts, in both cases, ordered that dismissal for incapacity was not supported by the evidence, ordering compensation to the one litigant ${ }^{[38]}$ and reinstatement of the other. ${ }^{[39]}$ In a third case, where the workplace environment contributed to the employee's mental ill health, again the 
incapacity was temporary, but the employer proceeded as if it was permanent. ${ }^{[40]}$ In that case, the court ordered that the dismissal of the employee was unfair, as reasonable accommodation was not offered, including the removal of the work stressors.

It is clear that health professionals have an important role to play in educating and informing employers of the difference between incapacity (temporary or permanent) and disability. In all instances, alternatives to dismissal, adaptations to working conditions or reasonable accommodation should be offered to the employee before dismissal is contemplated. Where the employer considers dismissing the employee specifically because of his or her psychosocial disability, it is considered automatically unfair, as such conduct constitutes unfair discrimination (on the basis of health, which is analogous to disability or the persons' mental condition). ${ }^{[4]]}$ The courts have noted and sanctioned the dignity infringements that have occurred in instances where employers have prejudiced the employee because of his or her psychosocial disability.

Our courts have consistently held that prior to dismissal for incapacity, accommodation should be offered and that in instances of poor work performance, the impact of the person's psychosocial impairment or disability has to be considered by employers, with an opportunity to improve, before proceedings are initiated to dismiss the person.

\section{Stigma and attitudinal barriers}

International law considers attitudinal and environmental barriers as significant obstacles that hinder participation on an equal basis with others, including in the workplace. ${ }^{[2]}$ In SA, attitudinal barriers remain a major obstacle for retention of employees with psychosocial disabilities (and to an extent other disabilities). ${ }^{[42]}$ The stigma associated with psychosocial impairment fosters expectations that a person with psychiatric disability will have a reduced capacity to work. Such assumptions often rest on oversimplified linkages between diagnoses (with associated symptoms) and reduced capacity to work, without sufficient consideration of environmental facilitators and barriers that impact ability and participation.

\section{Judgement of competence and ability}

Judgements about the readiness or ability of persons with psychosocial disability to work cannot be made solely on the basis of a diagnosis. Yet, an automatic tendency has been to anticipate incompetence or a reduced ability to maintain work in so far as people with psychosocial disability are concerned. Such practices have led to the exclusion of people with psychosocial impairment from work, thus turning their impairment into a disability. The episodic nature of psychosocial impairment too is not easily understood, and temporary incapacity is thought by employers to amount to permanent incapacity, as illustrated in the cases reviewed earlier.

Efforts to define competence have been shown to be fraught with complexities, to such an extent that Holahan ${ }^{[43]}$ introduced her inquiry on the connection between occupation and competence by stating that 'efforts to elucidate the meaning of competence might seem futile. ${ }^{[43]}$ Findings of her review suggest the notion of competence to be 'socially constructed, resourced, determined and contested and, as such, may serve as a positioning mechanism for not only the actor, but the whole occupational situation, ${ }^{\text {[43] }}$ Holahan's inquiry problematised simplified assumptions that situate competence within the individual, without adequate consideration of the dichotomous separation of the social from the individual, internal and external, or action and condition. ${ }^{[43]}$

Occupational therapists understand this dichotomous separation, and use comprehensive functional capacity evaluations to describe the nature and extent of incompetence and dysfunction in the individual with physical and psychosocial impairments. They also do an assessment of the occupational or work setting using techniques such as job analysis and evaluations of the work environment (both ergonomic and the social dynamic) ${ }^{[44]}$ to determine the interplay of the condition, the individual, the job demands and the occupational setting. Without these comprehensive functional capacity evaluations, it would be difficult to judge competence and ability or the lack thereof.

\section{Management of disability in work}

Health practitioners tend to underestimate the benefits of work shown in present-day research. ${ }^{[5]}$ For example, recovery has been shown to be faster and more successful if people can do some work while recovering. ${ }^{[45]}$ Better recognition of the potentially negative consequences of well-intended efforts to encourage and/or assist a patient to be medically boarded is required. Many medical doctors appear to be unaware of the potential harm that medically excused prolonged time off work can cause. ${ }^{[45]}$ Longitudinal studies have revealed that once a person commences certified work absence, they commonly start down a slippery slope that leads to long-term worklessness, because work absence tends to perpetuate itself - that is, the longer someone is off work, the less likely they become ever to return. ${ }^{[46]}$ It is estimated that $50 \%$ of people out of work for 8 weeks will not return to work, and $85 \%$ of people out of work for 6 months or more will never return to work on a sustained basis. ${ }^{[47]}$

Work is a fundamental part of our life, and by virtue of being employed, we are able to earn money and participate in society. ${ }^{[4]}$ It gives life meaning for most individuals, and provides income for meeting needs, e.g. food, shelter, clothing and medical care. ${ }^{[49]}$ The effects of not working are linked with problems such as interpersonal conflict, lower self-esteem, substance abuse and other mental health problems. ${ }^{[49]}$ Research has shown that prolonged certified work absence is harmful to the individual's health. ${ }^{[50]}$ The effects of not working include a progressive deterioration in physical and mental health, deterioration in interpersonal relationships with family and friends, loss of identity, financial hardship, a general deterioration of quality of life and a six-fold increase in the rate of suicide. ${ }^{[50]}$

Cessation of work due to being medically boarded for people with psychosocial disability is associated with increased mortality from cardiovascular disease and lung cancer. They are more susceptible to respiratory infections, and have higher rates of medical consultation, medication consumption and hospital admissions. ${ }^{[5]}$

Return to work, however, should happen in a conducive environment for long-term recovery and optimal work performance, and this may require reasonable accommodation measures for the returning employee. The role of health practitioners in this regard is vital not certifying prolonged work absence where it is not needed, and recommending provision of relevant accommodations where necessary.

Occupational justice is about recognising and providing for the occupational needs of individuals and communities as part of a fair and empowering society. ${ }^{[51-57]}$ When people's occupational 
engagement is prevented by a set of external limitations on their choices and/or opportunities, occupational injustice will be the result. ${ }^{[58]}$ The stigma associated with psychosocial disability causes the type of exclusion that leads to occupational injustice, particularly in an environment where opportunities for occupational engagement are further limited by resource constraints. Occupational injustice can be counteracted through recognition of the occupational nature and needs of people, and through the creation of inclusive work environments in which persons with psychosocial disability can participate. ${ }^{[58]}$

While decent work and just and fair conditions of work are recognised internationally and domestically, the SA Constitution does not recognise a 'right' to work. ${ }^{[59]}$ It is trite to state that work is 'a major positive factor for psychosocial health and recovery from illness, which links it inextricably with the right to attain the highest standard of psychosocial health'.[1]] The United Nations Economic and Social Council in 2000 urged states to recognise the links between occupational health and safety, including the promotion of psychosocial health and safety, and the rights to health, a healthy environment, and safe and healthy working conditions. ${ }^{[60]}$

\section{Conclusions}

The continued dominance of remedial focused service provision, without follow-through in terms of advocacy, suggests that most health practitioners are not actively advocating for the rights of the clients they serve. This might have been due to practitioners considering themselves ill-equipped to perform the role, not recognising the importance of advocacy, or a lack of awareness in terms of their responsibility for such a role.

All practitioners in the mental health field are morally obligated to advocate for those in vulnerable positions, specifically in this instance persons with psychosocial disability. They have an ethical responsibility to advocate for the rights of persons with disability and to protect persons with disability against unfair discrimination, including at places of employment. To this end, improved legal knowledge would be particularly useful, with the potential to inform practice.

The challenge is also the stigma faced by persons with psychosocial disability in the workplace, and the lack of awareness of measures to support them to attain and retain work on the part of employers. ${ }^{[56,58,60]}$ Practitioners can play an educative role for both their clients and for employers to address the stigma, avoid discrimination and empower stakeholders to ensure equal participation in the workplace with the measures that allow this to occur.

If the potential of participation in work as a means to fulfil a broad range of needs is accepted, it would follow that the availability of work to all who wish to participate in it is an important consideration. We argue that the ethical duties of health practitioners include playing an advocacy role to assist persons with psychosocial disability either to stay at work or return to work as soon as possible. Towards this goal, employers should be reminded that they also have a moral and ethical duty towards their employees to not to discriminate against workers with disabilities due to psychosocial impairment. ${ }^{[61]}$

An improved understanding of the potential dangers of sick leave in the absence of a stay-at-work or return-to-work plan will raise doctors' awareness of their role in managing problems associated with sickness certification. Guidelines by the South African Society of
Psychiatrists to the assessment of psychiatric impairment advocate for a disability-prevention approach, encouraging all healthcare practitioners to educate themselves on the dangers of prolonged illness absence. ${ }^{[62,63]}$ Such an approach would entail early referral of any person being booked off for more than 1 month owing to psychosocial disability to an occupational therapist with a view to vocational rehabilitation and a return-to-work plan. ${ }^{[61,63]}$ Doctors and other healthcare practitioners, including psychologists, should all assist in educating the public about the dangers of prolonged illness absence, and changing attitudes towards prescribing long periods of work sick leave in the absence of a stay-at-work or return-to-work plan. ${ }^{[6]]}$

The SA Human Rights Commission's (2017) Disability Toolkit ${ }^{[64]}$ for private sector employees may assist in monitoring future progress. In the meantime, psychiatrists and occupational therapists could be said to play an inadvertent political role when completing their workplace assessments in relation to disability, particularly in the case of affirmative action.

Recognition of the political nature of disability as a vehicle that might rightfully be used by a person with disability to unlock resources or opportunities for participation as a beneficiary of affirmative action embedded in the Employment Equity Act is required. The full potential of categorising persons with disabilities as beneficiaries for affirmative action and broad-based black economic empowerment has not yet been realised.

Tendencies to define and manage disability intraprofessionally will perpetuate the gaps in service delivery that broaden the chasm that persons with disability are left to cross on their own if they wish to enter and maintain employment. Interprofessional conceptualisation of best practice guidelines, informed by service users, should recognise the particular strengths of different role players. Evidenceinformed guidelines are needed to clarify which professionals should be involved in assessments to determine whether or not a person is indeed disabled. Related concepts that should be defined include the phrase 'substantially limiting', and the process that should be followed to be 'declared disabled' in SA, whether permanently or temporarily. The introduction of a certificate of disability is worth exploring as a strategy to clarify issues and close some of the gaps identified.

Our main objective with this article is to highlight gaps in service provision that negatively affect the employment of persons with psychosocial disability. The benefits of participation in work have been revisited with a particular focus on health outcomes for persons with psychosocial disability. We illustrate that gaps arise where professional fields overlap, and argue for service provision that seamlessly crosses professional boundaries. To this end, health professionals require a better understanding of labour legislation that protects patients' rights, and are challenged to broaden their support to include work-related outcomes. Legal professionals also need a better understanding of the difference between diagnosis and prognosis of psychosocial impairment from a medical perspective, how continued work benefits mental health, how reasonable accommodation measures can ameliorate barriers to full participation in the workplace, and that temporary or episodic impairment that may require some reasonable accommodations should not be misconstrued as permanent incapacity. Until these gaps are addressed, people with psychosocial disability will continue to find themselves invisible, isolated and discriminated against. 


\section{Acknowledgements. None.}

Author contributions. CG identified a gap in the field of psychosocial disability and work that would best be addressed by synthesising multiprofessional perspectives. He invited the authors to contribute based on their research and practice experience and perspectives. LvN took the lead during the writing process, incorporating contributions made by all authors who participated in conceptualising, writing and editing the manuscript.

\section{Funding. None.}

Conflicts of interest. None.

1. Motsoaledi M. Foreword by the Minister. In: National Department of Health (editor). Framework and Strategy for Disability and Rehabilitation Services for South Africa. Pretoria: NDoH, 2015.

2. United Nations. Convention on the Rights of Persons with Disabilities. New York: United Nations, 2007. https://www.un.org/disabilities/documents/convention/ convoptprot-e.pdf (accessed 20 October 2018).

3. Marmot M, Allen J, Bell R, Bloomer E, Goldblatt P. WHO European review of social determinants of health and the health divide. Lancet 2012;380(9846):1011-1029. https://doi.org/10.1016/s0140-6736(12)61228-8

4. Rosenthal L, Carroll-Scott A, Earnshaw VA, Santilli A, Ickovics JR. The importance of full-time work for urban adults' mental and physical health. Soc Sci Med 2012;75(9):1692-1696. https://doi.org/10.1016/j.socscimed.2012.07.003

5. Waddell G, Burton AK. Is work good for your health and well-being? London: The Stationery Office, 2006.

6. Harnois G, Gabriel P. Mental Health and Work: Impact, issues and good practice. Geneva: World Health Organisation, 2000.

7. Oliver M. The Social Model in action: If I had a hammer. In: Barnes C, Mercer G, editors. Implementing the Social Model of Disability: Theory and Research. Leeds: The Disability Press, 2004:18-31

8. Stein DJ, Phillips KA, Bolton D, Fulford K, Sadler JZ, Kendler KS. What is a mental/ psychiatric disorder? From DSM-IV to DSM-V. Psychol Med 2010;40(11):17591765. https://doi.org/10.1017/S0033291709992261

9. Kleintjes S, Lund C, Swartz L. Barriers to the participation of people with psychosocial disability in mental health policy development in South Africa: A qualitative study of perspectives of policy makers, professionals, religious leaders and academics. BMC Int Health Hum Rights 2013;13(1):17. https://doi. org/10.1186/1472-698X-13-17

10. Favalli S, Ferri D. Tracing the boundaries between disability and sickness in the European Union: Squaring the circle? Eur J Health Law 2016;23(1):5-35. https:// doi.org/10.1163/15718093-12341392

11. Burger P, Burger K. Defining Disability. Johannesburg: National Council for Persons with Physical Disabilities in South Africa, 2010.

12. Van Niekerk Z, Van der Merwe J. Participation opportunities for persons with disabilities in training interventions in the DTI and CIPRO. SA J Hum Resource Management 2013;11(1):1-12. https://doi.org/10.4102/sajhrm.v11i1.466

13. South Africa. Section 9(3) of the Constitution of the Republic of South Africa 1996https://www.refworld.org/docid/3ae6b5de4.html (accessed 14 October 2019)

14. South Africa. Section 10 of the Constitution of the Republic of South Africa https://www.refworld.org/docid/3ae6b5de4.html (accessed 14 October 2019).

15. South Africa. Section 23(1) of the Constitution of the Republic of South Africa 1996. https://www.refworld.org/docid/3ae6b5de4.html (accessed 14 October 2019]).

16. South Africa. Section 22 of the Constitution of the Republic of South Africa. 1996. https://www.refworld.org/docid/3ae6b5de4.html (accessed 14 October 2019).

17. Nielsen LB, Berrey EC, Nelson RL. Dignity and discrimination: Employment civil rights in the workplace and in courts. Chi-Kent L Rev 2017;92:1185.

18. Fredman S. Facing the future: Substantive equality under the spotlight. In: Dupper O, Garbers C, editors. Equality in the Workplace: Reflections from South Africa and Elsewhere. Stellenbosch: Stellenbosch University, 2010.

19. South Africa. Section 1 of the Employment Equity Act No. 55 of 1998. Government Gazette No. 19370:1323.

20. South Africa. Social Assistance Amendment Bill No. 5 of 2010. Amendment of Section 1 of Act No. 13 of 2004 of the Social Assistance Amendment Act. Government Gazette No. 32986.

21. Ngwena C. Deconstructing the definition of 'disability' under the Employment Equity Act: Social deconstruction. S Afr J Hum Rights 2006;22(4):613-646. https:// doi.org/10.10.1080/19962126.2006.11864904

22. Disabled People South Africa. Disability Rights Charter of South Africa Pretoria: DPSA, 1992.
23. African Union Assembly. Protocol to the African Charter on Human and Peoples' Rights on the Rights of Persons with Disabilities adopted by the African Union Assembly on 29 January 2018. Addis Ababa: African Union Assembly, 2018.

24. South Africa. Employment Equity Act No. 55 of 1998. Government Gazette No. 19370:1323.

25. South Africa. Section 6 of the Employment Equity Act No. 55 of 1998. Government Gazette No. 19370:1323.

26. South Africa. Clause 6.12 of the Code of Good Practice on the Employment of Persons with Disabilities. Government Gazette No. 39383:1085. 2015.

27. Department of Labour. Technical Assistance Guidelines on the Employment of Persons with Disabilities. Pretoria: Department of Labour; 2017 http://www. labour.gov.za/DOL/downloads/documents/useful-documents/employmentequity/tagdisability2017.pdf (accessed 20 October 2018).

28. South Africa. Clause 6.2 of the Code of Good Practice on the Employment of Persons with Disabilities. Government Gazette No. 39383:1085. 2015.

29. South Africa. Basic Conditions of Employment Act No. 75 of 1997.

30. South Africa. Labour Relations Act No. 66 of 1995. Government Gazette No. 16861:1877.

31. South Africa. Skills Development Act No. 97 of 1998. Government Gazette No. 37407:229

32. South Africa. Promotion of Equality and Prevention of Unfair Discrimination Act No. 3 of 2000.

33. Department of Trade and Industry, South Africa. The Broad-Based Black Economic Empowerment (BBBEE) strategy. http://www.thedti.gov.za/economic empowerment/bee-strategy.pdf. (accessed 4 June 2018).

34. South Africa. Compensation for Occupational Injuries and Diseases Bill of 2018 Government Gazette No. 41985:1133.

35. Statistics South Africa. StatsSA Census 2011: Profile of Persons with Disabilities in South Africa, Report 03-01-59. Pretoria: StatsSA2014.

36. Standard Bank of South Africa v CCMA 2008 (29) ILJ 1239 (LC).

37. Bassuday K \& Rycroft A. Incapacity or Disability? The Implications for Jurisdiction Ernstzen v Reliance Group Trading (Pty) Ltd. 2015 (C717/13) ZALCCT 4236 (ILJ) 2516.

38. IMATU obo Strydom v Witzenberg Municipality 2012 (33) ILJ 1081 (LAC).

39. Spero v Elvey International (Pty) Ltd. 1995 (16) ILJ 1210 (IC).

40. Bennett v Mondipak 2004 (25) ILJ 583 (CCMA).

41. New Way Motor \& Diesel Engineering (Pty) Ltd. v Marsland 2009 (30) ILJ 2875 (LAC).

42. Hussey M, MacLachlan M, Mji G. Barriers to the implementation of the health and rehabilitation articles of the United Nations convention on the rights of persons with disabilities in South Africa. Int J Health Policy Management 2017;6(4):207. https://doi.org/10.15171\%2Fijhpm.2016.117

43. Holahan LF. Quality-in-doing: Competence and occupation. J Occup Sci 2014;21(4):473-487. https://doi.org/10.1080/14427591.2013.815683

44. Buys T, van Biljon H. Functional capacity evaluation: An essential component of South African occupational therapy work practice services. Work 2007;29(1):31-36.

45. Sawney P. Current issues in fitness for work certification. $\mathrm{Br} J$ Gen Prac 2002;52(476):217-222.

46. Johnson D, Fry T. Factors affecting return to work after injury: A study for the Victorian WorkCover Authority. Melbourne: University of Melbourne, 2002.

47. Talmage JB, Melhorn JM, Hyman MH. AMA Guide to the Evaluation of Work Ability and Return to Work. 2nd ed. USA: American Medical Association, 2011.

48. Van Niekerk L. Participation in work: A human rights issue for people with psychiatric disabilities. S Afr J Occup 2008;38(1):9-15.

49. Blustein DL. The role of work in psychological health and well-being: A conceptual, historical, and public policy perspective. Am Psychologist 2008;63(4):228. https:// psycnet.apa.org/doi/10.1037/0003-066X.63.4.228

50. Dunstan DA. Are sickness certificates doing our patients harm? Austral Fam Physician 2009;38(1/2):61.

51. Durocher E, Gibson BE, Rappolt S. Occupational justice: A conceptual review. J Occup Sci 2014;21(4):418-30. https://doi.org/10.1080/14427591.2013.775 692

52. Dupper O, Govindjee A. Constitutional perspectives on unemployment security and a right to work in South Africa. Stellenbosch Law Rev Stellenbosch Regstydskrif 2011;22(3):775-803

53. United Nations Human Rights Office of the High Commissioner. Article 6 and 7 of the International Covenant on Economic, Social and Cultural Rights. Geneva: UNHCR, 1976. https://www.ohchr.org/en/professionalinterest/pages/cescr.aspx (accessed 20 October 2018).

54. United Nations. Article 27 of the Convention on the Rights of Persons with Disabilities. Geneva: UN, 2007. https://www.un.org/disabilities/documents/ convention/convoptprot-e.pdf (accessed 20 October 2018).

55. International Labour Organisation. Convention concerning Occupational Safety and Health and the Working Environment. Geneva: ILO, 1981. https://www.ilo. org/dyn/normlex/en/f?p=NORMLEXPUB:12100:0::NO::p12100_instrument id:312300 (accessed 25 November 2018).

56. Holness W. The invisible employee: Reasonable accommodation of psychosocia disability in the South African workplace. S Afr J Hum Rights 2016;32(3):510-537. https://doi.org/10.1080/02587203.2016.1258197 
57. Durocher E, Kinsella EA, McCorquodale L, Phelan S. Ethical tensions related to systemic constraints: Occupational alienation in occupational therapy practice. OTJR: Occupation Participation Health 2016;36(4):216-226. https://doi. org/10.1177\%2F1539449216665117

58. Mahomed F. Stigma on the basis of psychosocial disability: A structural human rights violation. S Afr J Hum Rights 2016;32(3):490-509. https://doi.org/10.1080/ 02587203.2016.1258199

59. United Nations. CESCR General Comment No. 14: The Right to the Highest Attainable Standard of Health (Art. 12). Geneva: UN, 2000. https://www.refworld. org/pdfid/4538838d0.pdf (accessed 25 November 2019).

60. Du Plessis MC. Access to work for disabled persons in South Africa: A rights critique. Pretoria: PULP, 2017

61. Grobler G, Grobler C, Korb F, Lippi G, Zilesnick S, Allers E. SASOP Guidelines to the management of impairment claims on psychiatric grounds. Pretoria: South African Society of Psychiatrists, 2017. https://www.asisa.org.za/wpcontent/ uploads/2018/04/SASOP-Guidelines-to-the-Management-of-ImpairmentClaimson-Psychiatric-Grounds-2017.pdf (accessed 16 April 2018).
62. Grobler C. Sick leave and work absence. Part 2: Returning to work after prolonged sickness absence: A psychiatrist's perspective. Occup Health South Afr 2018;24(3):63-65.

63. Grobler C, Lapere J. Sick leave and work absence Part 1: Can sick leave be harmfu to patients? Back to basics. Occup Health South Afr 2016;22(3):17-19.

64. South African Human Rights Commission. Disability Toolkit: A quick reference guide and monitoring framework for employers. Johannesburg: South African Human Rights Commission, 2017. https://www.sahrc.org.za/home/21/ files/20170524\%20SAHRC\%20Disability\%20Monitoring\%20Framework\%20 and\%20guidelines\%20Draft\%205.pdf (accessed 23 June 2020).

Accepted 27 May 2020. 